\title{
ENHANCING COMPETITIVENESS OF INDONESIAN FOOD AND BEVERAGE INDUSTRY THROUGH ADOPTION FACILITIY OF QUALITY ASSURANCE PROGRAMS
}

\section{Mempertinggi Daya Saing Industri Makanan dan Minuman Indonesia melalui Fasilitas Penerapan Program Jaminan Mutu}

\author{
Agus Sudibyo ${ }^{1}$ and Aslam Hasan ${ }^{2}$ \\ ${ }^{1}$ Center of Agro-Based Industry, Jl. Ir. H. Juanda No. 11, Bogor, 16122, West Jawa, Indonesia \\ ${ }^{2}$ Directorate of Tobacco and Beverage Industry, Directorate General of Agro Industry and Forestry Products, \\ Ministry of Industry, Indonesia \\ E-mail: asdibyo_as@yahoo.co.id
}

Diterima: 21 Maret 2016, Direvisi: 1 September 2016, Disetujui: 6 September 2016

\begin{abstract}
A survey of 102 small to medium sized food processors and manufactures in DKI, West Jawa and Banten province, Indonesia has been conducted for to know the quality assurance (QA) program. The survey was carried out with method to identify and to distribute a questionnaire and also to interview to small and medium scale food industry respondents selected that develope the QA program. The results of the study reveals that the main reasons for implementing one or more quality assurance (QA) programs in the food business were satisfy/meet customers requirements, to seek the highest standard of quality and food safety, provide cotinous quality control and maintenance, reduce legal liability, improve the business structure, facilitatenew market entry and/or to expand market size and sales. Conversely, the main reasons for not implementing one or more QA programs were : the cost of QA implementation and maintenance of QA programs to high, there was no need or no legal requirement to implement QA, the businees was too small. There was insufficient time, a lack of information or lack of resources. The failure to implement QA systems has the potential to exclude small and medium sized food processors and manufactures from many domestic and international markets.
\end{abstract}

Keywords: Enhancing, competitiveness, food and beverage industry, adoption, quality assurance.

\begin{abstract}
Abstrak
Suatu survei terhadap 102 industri kecil dan menengah pengolah pangan di provinsi DKI, Jawa Barat dan Banten telah dilakukan untuk mengetahui program jaminan mutu perusahaan. Survei ini dilakukan dengan cara mengidentifikasi dan menyebarkan daftar pertanyaan (kuesioner) serta melakukan wawancaa ke industri pengolah yang terpilih dalam mengembangkan sistem jaminan mutunya. Hasil survei dan identifikasi menunjukkan bahwa alasan utama untuk mengimplementasikan satu atau lebih program jaminan mutu pada perusahaan adalah untuk memuaskan persyaratan pelanggan, mencari standar tertinggi terhadap mutu dan keamanan pangan, menyediakan cara pengendalian mutu yang berkelanjutan dan menjaganya, mengurangi pertanggung-jawaban legal, memperbaiki struktur bisnis perusahaan, untuk mempermudah masuk ke pasar baru dan mengembangkan ukuran pasar dan penjualan. Sebaliknya, alasan utama tidak mengimplementasikan satu atau lebih program jaminan mutu pada perusahaan industri pangan tersebut adalah : biaya yang diperlukan untuk menerapkan dan menjaga program jaminan mutu tinggi, tidak adanya kebutuhan atau persyaratan legal untuk penerapan jaminan mutu, bisnis pangan yang mereka kerjakan termasuk kecil, dan ketidakcukupan ketersediaan waktu untuk penerapan jaminan mutu, serta kurangnya informasi dan sumberdaya. Kegagalan untuk mengimplementasikan sistem jaminan mutu pada industri kecil dan menengah pangan berpotensi dilarang masuknya produk mereka masuk ke pasar domestik dan internasional.
\end{abstract}

Kata kunci: mempertinggi, daya saing, industri makanan dan minuman, adopsi, jaminan mutu. 


\section{INTRODUCTION}

The Indonesian food and beverage industry now is recognized enough worldwide for its variety, good quality and healthy image, innovative manufacturing and packaging technologies. The diversity of foodstuffs available from Indonesia is huge and comprises grains, meats, diary products, seafood, fruits and vegetables, bakery products and bakery goods, oils and fats, chocolate and confectionery, coconut products, soft drinks, spices and seasonings, bottled tea, bottled coffee, and other beverages and a host of individual gourmet treats and speciality lines.

Ethnic and cultural diversity in Indonesia is reflected in the wide range of food available with many Asian, European/American and Middle Eastern influenced speciality products. Indonesian food producers can also cater to specific consumer needs in terms of certified organic, halal foods and speciality foods.

The food industry (small, medium and large scale industry) is large and vital parts of the Indonesia economy. In the 2011 - 2013, total consumer expenditure on food and liquor was nerly IRD 629 billion, around $31.29 \%$ of total Indonesian retail turnover (Indonesian Association of Food and Beverage or GAPMMI, 2013). However, the value of Indonesian food exports declined by around $4 \%$ in $2012-2014$ to IRD 120 billion. Food exports reach a peak of IRD 162 billion in $2007-2010$ and have seen declining ever since. The reason are the drought, climate changes, decrease in productivity, lack of innovations and changes in import from overseas customers (National Body of Statistics, 2011).

At the same time, there has been a dramatic increase in the number (especially lessdeveloped ones) involved in the production of foods for exports. More than $50 \%$ of the fruits and vegetable, sugar, non-alcoholic beverages, fish and fishery products are exports from developing contries (Marucheck et al., 2011).

Meanwhile, food safety has been the subject of increased attention in public regulation, private supply chain coodination, and international trade for the past two decades (Unnevehr and Ronchi, 2014). From a safety perspective, food supply chains hav a number of vulnerabilities (Whipple et al., 2009). Firstly, they deal with natural products, many of which are perishable and could become harmful to consumers if not managed in timely and safe manner (Akkerman et al., 2010). Secondly, food supply chains tend to be long, global and highly interconnected, leading to greater risk exposure (Trieneckens and Zuurbier, 2008; Whipple et al., 2009). Thirdly, food and beverage products are at the risk of international or uninternational adulteration and could even be the target of 172 terrorist threats (Whipple et al., 2009). Moreover, the emergence of new and more stringent food safety standard is the results of several factors, including the growth in trade of perishable and high value products, advances in hazards detection and epidemiology, high-profile health scares, scientific and regulatory consensus on best approach to risk management, and recognation of global standards and approaches under the framework of the World Trade Organization/WTO (Unnevehr and Ronchi, 2014).

For food business or food industries this implies placing more emphasis on quality and safety control, on trace ability of food products and on environmental issues and, at the same time, shifting from bulk productions towards production of specialities with high added value. Furthermore, because of their embededness in the global economy, collaboration with other parties become important for all business or all food industries to acheive safe and high-quality food products for the consumer. This means that business strategies must now move their focus from traditional economical and technological interest to topical issues such as the safety and health fullness of food products, animal friendliness, the environment, etc (Trienekens and Zuurbier, 2008).

Small and medium enterprises (SMEs) have an important role Indonesian economic (Iriyanti and Aziz, 2012; Pawitan, 2012; Setyaningsih, 2012). In Indonesia, small and medium sized enterprises (SMEs) represent $90 \%$ of all business enterprises are responsible for over $58 \%$ of the GDP. SME are comprised microbusiness $(94 \%)$, small business $(5 \%)$ and medium sized business (1\%). A significant number of small and medium scale food processing operations are regionally based (Tambunan, 2011).

In order to differentitive their product in congested market and to deal with these above challenges, companies around the world are increasingly using standard quality assurance systems to improve the quality and safety of products and production process. As a results food business or food industries have introduced a variety of quality assurance systems (Marucheck et al., 2011). For example, Multi National Corporate (MNC) food industries in Indonesia announced that it would required all indirect suppliers of product to have certified food safety and quality assurance programs. MNC food industries group have move beyond indicative market acces scenarios to implement barriers to supply, based on a certified quality and safety assurance process. Nestle, Unilever, Danone, Indofood, Garudafood, Coca Cola, Sosro bottled tea group; Mayorafood group, 
Olagafood, Japfafood group and any other food industries corporate group announced that they would require all suppliers of food for their private brand to be certified. A stages process was outlined in which suppliers of high risk products and low risk food suppliers would need to be certified of quality or safety. However, in Indonesia, less than $20 \%$ of 1500 plus registered food companies currently have certified food quality and safety programs. There are around 113 food industries that have been HACCP (Hazard Analysis and Critical Control Point) based on SNI CAC/RCP 1 : 2011 from certification body, that accredited by National Committee of Accreditation (Hilman and Ikatrinasari, 2014).

While most Indonesian food business recognise and acknowledge the important of operating under approved ISO 9001 and HACCP-based quality assurance (QA) program to deliver safe food, over time, there has been steady decline in the relative importance Indonesian food producers give to HACCP or ISO 22000-based quality assurance (QA) programs. As a results, the Indonesian food industry is ternd beginning to loose its competitive advantage. Moreover, marketoriented firms have been demonstrated to be successful at maintaining a strong competitive position (Najib et al., 2011). It occurs because of market-oriented behaviour lead the firms to be more innovative. In small firms or small scale and medium food industries, innovativeness implies a willingness of the owner to learn about and to adopt innovation, both in input and output markets. Forsman (2010), defines innovation as the generation and implementation of new or improved process, services, products, production methods/technologies or single actions aimed at increasing the competitiveness of enterprises. Competitiveness is guaranted by innovation and quality or safety upgrade (Parilli and Elola, 2011).

This study sought to identify the food safety and quality assurance programs that are currently being used by small and medium sized food processors and manufactures in Indonesia (specifically in DKI, West Jawa, and Banten province) and to identify the benefits, barriers and cost associated with the decision to adopt and to maintain one or more quality assurance program(s).

\section{LITERATURE REVIEW}

Several problems of Indonesian small and medium food processing industry such as capital, market acces, technology and management system make them difficult to develop competitiveness (Najib et al., 2011). According to Fatimah in 2007 that cited by Abdul et al., (2013) was said that $82 \%$ of the SMEs on food products in Indonesia have not yet implemented any quality nor safety management systems and among of them $39 \%$ did not know about quality system.

In term of diversification of the business environment and increasing competition, the quality is currently an important tool for the substantion of decision and the most important factor in increasing economic competitiveness of companies (Ionita et al., 2009). Meanwhile, quality assurance is important and gives a significant impact to the busiess performance (Thalib et al., 2013). In addition to the quality assurance, it is also vital to ensure a proper quality level of all the other product characteristics with reference to the consumer expectations. Thus, for the purpose of ensuring a suitable and accepted by consumers food quality, food operators should implemented quality assurance systems and quality management systems (Sikora, 2005).

Quality and food safety assurance affect the cost of carrying out transactions, and therein lies the private incentive for adopting voluntary food quality assurance programmes. Generally, quality assurance practice is measured by : (i) new product design review procedures; (ii) design for manufacturing procedures; (iii) control of products and work specifications and procedures; (iv) preventive maintenance activities; and (v) quality control activities along the value added chain (Thalib et al., 2013). Consequently, this construct is also concerned about the quality assurance practices, consist of guidance, manual, standard, and etc., in the aspects of their implementation in the organization.

\section{RESEARCH METHODE}

\subsection{Materials}

The materials used of this study consist of a questionnaire that was designed related to the facilitating the adoption of quality assurance (QA) programs and letters. The content of this questionnaires asked about facilitating the adoption QA programs (i.e. the business had no intention of implementing a QA program; the business has started to implement a QA programs; the business has successfully implemented a QA programs, and the business no longer had a QA programs).

The letters were purposed to collect the secunder data or to get some information related food safety or food quality matters of business in 
line with network institution (e.g. Ministry of Health, Ministry of Industry, Ministry of Trade, Ministry of Agriculture, Centre for Standardization, and National Agency for Drug and Food Controls).

\subsection{Methods}

The study was conducted in two phases. The first phase (July 2013 to December 2013) involved an exploratoty investigation of the Indonesian food processing and manufacturing sector with a view to identifying the characteristic of the industry and their influenced on the likelihood of the adopting quality assurance (QA) systems. A comprehensive questionnare was developed and pretested among a sample of QA managers, business owners and QA experts in personal interview acroos all indusstry sectors.

In the second phase, from March 2014 to Agust 2014, a postal survey to 342 food and beverage business/industries including face-toface interviews with respondents undertaken. For this research study, participants are selected from the following food and beverage sectors : (1) beverages, (2) snack food, (3) bakery products, (4) chocolate and confectionery products, (5) fats and oils, (6) diary products, (7) meat products, (8) seafood, (9) fruit and vegetables, (10) coffe products; (11) spices and seasonings; and (12) other foods.

Interview were mainly undertaken at the food processing level with a range of small amd medium sized enterprises (SMEs). SMEs are defined as non-subsidiary, independent firms, which employless than a given number of employees (OECD, 2000). This number varies across national statistical systems, but the most frequent upper limit is 100 employees (Tambunan, 2009). For this purposes of this study, SMEs are defined as those business employing less than 100 employees as the National Centre Agency of Statistic (BPS) or Ministry of Industry definition. In Indonesia, according to the state Ministry of Cooperative and SMEs (Menegkop and UKM), small enterprisess (SE) as business unit must have an annual value of sales of a maximum of IRD 1 billion, and a medium enterprise (ME) must have an annual value of sales more than IRD 1 billion but less than IRD 50 billion (Tambunan, 2009). For most SMEs, management and ownership of the firms are similar. In addition, the owner/manager has a huge influence on the performance of the business (Stoner, 2005).

Despite the initial size of the survey instrument, respondents only had to answer those questions which reflected the current stage to which quality assurance program(s) have been implemented, maintained or even abondoned within the business. The questionnaire was subdevided in section 1 and 2 and then categorized : (1) PART A : If the business had no intention of implementing a QA program; (2) PART $B$ : If the business has started to implement a QA program(s); (3) PART C : If the business has succesfully implemented a QA program(s); and (4) PART D : If the business no longer had a QA program(s).

All respondents were asked to describe : (1) the nature of their business (kind of products, number of employees, turn over/annual value of sales); (2) the organizational value system; (3) the markets which they currently supply/intend to supply; (4) the QA programs under which they operate or intend to operate; (5) the reason/motivation for adopting, maintaining or choosing not to adopt QA; (6) the positive and negative attributes of each systems; (7) the cost of implementation, monitoring and auditing; (8) the investment/cost of staff training; (9) the financial rewards/ benefits/incentives; and (10) the role/influence of government legislation.

The compeleted questionnaires were returned to the Directorate of Small Scale Industry - Ministry of Industry either electronically, via the fax or via the mail. Responses were encoded and enter into the Statistical Package for Social Science (SPSS, version 17).

\subsection{Frame Works of Study}

The frame works of this study were included : literatur study, making and preparing the questionnaire relates to the facilitating the adoption a quality assurance (QA) programs and food safety/quality management systems; conducting survey and interview to small and medium food enterprise (SME) at three provinces (DKI Jakarta, Banten and West Jawa); Data collecting, checking and processing; and Descriptive and Statistical Analysis).

The results of survey, an interview and response of the questionnaires were conducted analyze through descriptive analysis. To test if there were differences among four categorized of QA programs; a one-way statistical analysis of variance with Statistical Package for Social Science (SPSS, version 17) test were used. Test of significance were based on Chi-square statistics and stdudent t-tests to determine whether the food industries more likely to adoption QA programs. Concisely, a step of the study enhancing the international competetiveness of Indonesian food and beverage industry through facilitating the adoption of quality assurance programs was presented in Figure 1. 


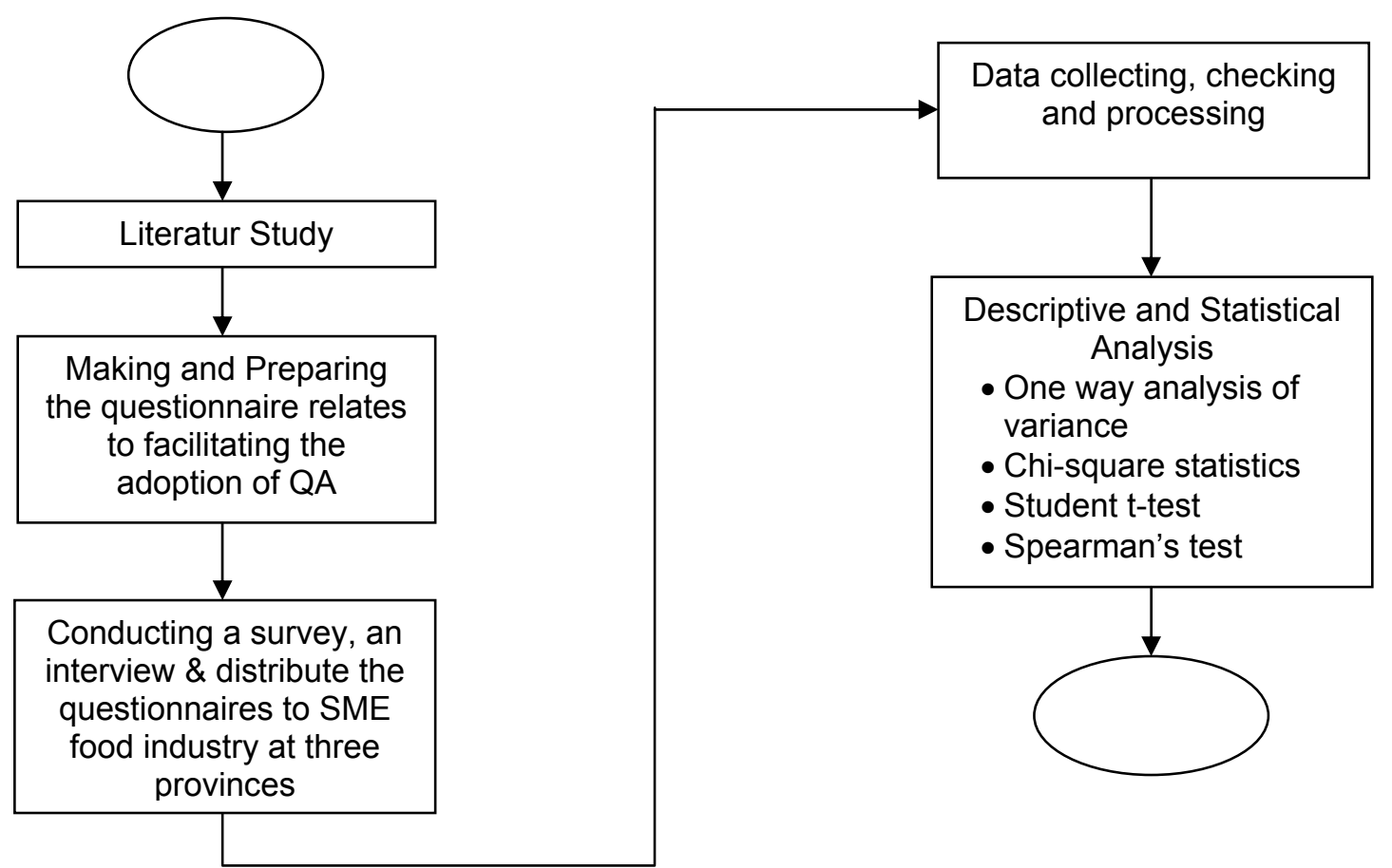

Figure 1 The steps of the study of enhancing the international competitiveness of Indonesian food and beverage industry through facilitating the adoption of QA programs.

\section{RESULTS AND DISCUSSION}

\subsection{Empirical Results}

A total numbers of 102 questionnaires were completed, which was indicative of a $37 \%$ response rate. Most respondents (23.50\%) belonged to the "beverage" manufacturing sector which included bottled drink water, bottled tea beverage, coffee beverages, and soft drink manufactures) or to the "snack foods" manufacturig sector $(16.7 \%)$ which included potato snacks, cassava snacks, extruded snacks based on wheat fluor products (Table 1).

Most of food and beverage businesses $(80.0 \%)$ derived all their sales from DKI, West Jawa and Banten Province domestic market. Conversely, a small group of respondents derived more than $28.0 \%$ of their sales from the export market. Most were privately owned $(72.0 \%)$.

Table 1 Respondents based on food and beverage products.

\begin{tabular}{|c|c|c|}
\hline Clasification of food and beverage products & Participants & Percetage (\%) \\
\hline $\begin{array}{l}\text { - Beverage manufacturing (bottled water, bottled tea, bottled coffee, } \\
\text { juice, energy drink, soft drink, etc.) }\end{array}$ & 24 & 23.53 \\
\hline - Snack foods (potato snack, cassava snack, extrudate snack, etc.) & 17 & 16.67 \\
\hline - $\quad$ Oil and fat manufacturing (cooking oil, margarine, mayonaise, etc) & 8 & 7.84 \\
\hline - $\quad$ Bakery manufacturing (cake, bread, biscuit, pastry, etc.) & 10 & 9.80 \\
\hline - $\quad$ Fruit and vegetables processing & 5 & 4.90 \\
\hline $\begin{array}{l}\text { Diary manufacturing (milk, milk powder, yohurt, ice cream, other } \\
\text { diary) }\end{array}$ & 7 & 6.86 \\
\hline $\begin{array}{l}\text { - Meat and meat products (poultry, meat ball, nugget, sausage, ham, } \\
\text { etc) }\end{array}$ & 10 & 9.80 \\
\hline - Spices and seasonings (spices powder, chilli sauce, ketchup, etc) & 5 & 4.90 \\
\hline $\begin{array}{l}\text { - Chocolate and Cocoa products (Cocoa powder, meyses, cocoa } \\
\text { butter, cocoa mass, chocolate bars, etc) }\end{array}$ & 5 & 4.90 \\
\hline - $\quad$ Other food manufacturing (seafood, animal, etc.) & 12 & 11.77 \\
\hline
\end{tabular}


It was immediately apparent that the financial turn over of the business had a significant impact on the extent to which the business had implemented a quality assurance program. For $50.0 \%$ of those business that di not intend to implement quality assurance (QA) or were currently in the process of implementing QA, their annual turn over or the annual value of sales less than IRD 1 billion. Conversely, for those business that had an operational QA systems, $85.0 \%$ were earning more than IRD 1 billion in sales (Table 2).

Table 2 Sample SMEs on food products by business size.

\begin{tabular}{lcccc}
\hline $\begin{array}{l}\text { Survey statements (N = 103) survey parti- } \\
\text { cipants (Number) }\end{array}$ & Part A & Part B & Part C & Part D \\
\hline < IRD 200.000 & $\mathbf{3 1}$ & $\mathbf{2 0}$ & $\mathbf{4 4}$ & $\mathbf{7}$ \\
\hline IRD 200.000 - 500.000 & 14 & - & - & 1 \\
\hline IRD 500.000 to 1 billion & 8 & 1 & 3 & 2 \\
\hline IRD 1 billion to 3 billion & 5 & 2 & 5 & 2 \\
\hline IRD 3 billion to 5 billion & 3 & 6 & 6 & - \\
\hline > IRD 5 billion & 1 & 5 & 12 & - \\
\hline
\end{tabular}

(turn over, in IRD 000,-)

\subsection{Quality Assurance Programs in Indonesia}

The Codex Alimentarius Commission in 2006 that as cited by Ojinnaka (2011), stated that producers at all stages of production, processing and distribution must be responsible for safe food and should establish food safety assurance programs; while the government on other hand, plays the primary role of providing leadership for the implementation of the food safety assurance. Therefore, the establishment of effective food safety systems is pivotal to ensuring the safety of the national food supply as wells as food products for regional and international trade ( Mwamakamba et al., 2012). As a results, Indonesia needs to take appropriate and pragmatic steps to ensure food safety and quality for domestic and export. Thus, for the purposes of ensuring a suitable and accepted by consumers food quality, food operators/food industries should implement quality and safety assurance systems (e.g. HACCP; ISO 22000) and quality management systems (for example according to standards of ISO series 9000).

These quality assurance programmes are designed to ensure customers that agreed-upon (contractual) product characteristics and/or production process are consistently delivered. Quality assurance for food itself can be defined as products to which in the entire chain of gaining, food processing, distribution up to consumer; there were applied systems that guaranted meeting the quality requirements, which anabled obtaining product with expected parameters (Sikora, 2005).

Consequently, foods and beverages sold in Indonesia must meet stringent food quality and safety standards. There are various levels of food legislation enforced by national, state and local authorities that provide a framework to protect the safety of the food supply chain and minimize the risk to public health. Within Indonesia, food safety and enforcing food standards is responsibilities of the Ministry of Health, National Agency for Drug and Food Control (NADFC), Ministry of Agriculture and Estate Crops, Ministry of Ocean and Fishery, National Agency for Standardization (BSN) under the food law/Act Number 18 in 2012; Consumer Protection Act Number 8 in 1999; Law Number 9 of 1985 concerning Fisheries; Law Number 6 of 1967 concerning stipulation for animal husbandary and health of livestock; Government Regulation Number 28 of 2004 about Food safety, Quality and Nutrition; Government and Ministry of Industry Regulation Number 75/MIND/X/2010 concerning good manufacturing practice (GMP); Food safety standards like Indonesian National Standard (SNI) CAC/RCP $1: 2011$ based on GMP and HACCP systems; MD certification for domestic product and ML certification for import product authority by NADFC; and also conjunction with local government jurisdictions.

The most common quality and safety assurance system operating in the Indonesian food industry were includes and classified according to the extent of activities they cover, in : basic safety systems as prerequisites (good agriculture practice/GAP, good hygiene practice/GHP, good manufacturing practice/GMP); basic quality management systems - ISO 9001; advanced safety systems such as HACCP, and integrated food safety management - ISO 22000. Among of these quality and safety assurance was third party certified standards have adopted the HACCP principles to manage both quality and food safety. 
For those businesses (food industries) that were implementing quality assurance (Part B), the most frequently reported systems were ISO 9000(1) series (56.0\%); HACCP (61.0\%), Hygiene Code $(31.0 \%)$, and GMP $(37.0 \%)$. While for those food industries that were already operating under one or more quality assurance programs (Part $\mathrm{C}$ ), the most frequently reported systems were ISO $9000(1)$ series $(63.0 \%)$, HACCP $(72.0 \%)$; Hygiene Code $(37.0 \%)$ and GMP (41.0\%).

For the small number of respondents who had abondoned their quality assurance (QA) program were $9.0 \%$. The main reason for doing so was the lack of any commercial benefits $(60.0 \%)$ and no need or legal requirement in Indonesia to operate under a quality assurance (QA) systems (40.0\%).

From the above information, it could be stated that implementing of quality/safety assurance programs in Indonesia need to be improved and developed. Because looking at in the previous research as claimed by Fatimah (2007), based on the surveys in several parts in West Jawa (Bandung, Subang, Garut, Purwakarta, Sukabumi, Ciamis, Sumedang, Cianjur, Kuningan, Bekasi, Majalengka and Cirebon) was showed that, $82.0 \%$ of the SMEs on food product have not yet implemented any qualification safety management systems and among of them $39.0 \%$ did not know about quality systems. Among of the respondents who have implemented quality systems $(16.0 \%)$, the levels quality/safety standrds remains only at One Star and Two Star Award levels. Whereby, One Star levels indicates that the enterprise has trained and implemented the food safety principles; and two Star Award levels indicates that the enterprise has implemented good practices for food processing. Two Star Award itself is quality/safety assurance that launched by NADFC (Badan POM) and aligned with Codex principles of food hygiene and help business develop good safety practices (Nababan et al., 2004).

However, a further research report claimed by Fatimah (2007), that they failed to implemented Hazard Analysis and Critical Control Point or HACCP standard and Quality management Systems (QMS) standard (ISO 9000 series). In order to export their products, they should comply with the importing country's and buyers' requirements, such as having import - export certification, comply with food safety and quality standards, comply with system equivalence assessment, comply with risk analysis verification and prioritizing control measures (Abdul et al., 2013). Because different importing countries have different standards and regulatory approaches, even for the same type of food product with the same health concern, packaging and processes (Othman, 2010). Thus, this indicates that SMEs do not have the capacity to export their product yet. Their market is merely based at domestic only.

\subsection{The Motivation to Use a QA Program}

The food companies or food industries gave many reasons for the decision to introduce a quality or safety assurance. The reasons for the implementation of quality asurance (QA) programs might come from the company itself, the parent company or from customer (Judi et al., 2013). In spite of the fact that it is voluntary, it is obvious that if a business does not comply with customer's requests, and as a results it will be difficult to enter some markets, both domestic and international or to achive the status of an "approved" supplier (Unnevehr and Ronchi, 2014).

Based on the surveys, for those food businesses who had decided to implement one or more quality assurance (QA) programs (Part $B$ ), the main reasons for doing so were : (1) satisfy or to meet customer requirements, e.g. required by supermarkets, franchise companies, fast food companies and wholesalers (48.0\%); (2) to seek the highest standard of quality and food safety $(43.0 \%)$; (3) to achieve continous food safety, quality control and maintenance (23.0\%); (4) to reduce legal liability $(16.0 \%)$, and improved business struvture (18.0\%); and (5) to facilitate new market entry or to expand market size and sales (23.0\%).

The survey also revealed that $49.0 \%$ of enterprises were driven by expected marketing and advantage that could be derived from implementing the standards, others $31.0 \%$ saw the potential for improved corporate image, and $20.0 \%$ claimed that their certification was motivated by the fact their competitors were certified.

For those food businesses or food industries already operating one or more quality assurance program (Part $\mathrm{C}$ ); the main reasons for having doing so were to : (1) satisfy or to meet customers requirements $(59.0 \%) ;(2)$ to seek the highest standard of quality and safety (43.0\%); (3) to achieve continous food safety, quality control and maintenance (35.0\%); (4) to gain a competitive advantage/market leadership $(21.0 \%)$, and (5) greater food safety/consumer confidence $(17.0 \%)$.

One of the main incentives was desire by the food company to participate in P-IRT certification (certification for small scale food 
industry) and in MD certification for domestic products as food marketing and distribution schemed under managed and regulated by National Agency for Drug and Food Control (NADFC) or Badan POM. This program provides the Indonesian consumers with the assurance that they are supporting the local and national food industry by purchasing safe, good quality Indonesian food products that are made primarily from Indonesian ingredients. To be eligible to use the certificate, the food business or the food industries had to have a food safety assurance scheme or quality/safety protocol in place. Basically, most of the respondents were aware the process involved in the P-IRT or MD certification and agreed that by having their products safety certified (P-IRT and MD certification) could promote customers' satisfaction, confidence and trust, besides able to boost their market share and market competitiveness; because P-IRT or MD certification is a mandatory principle as regulated by the Indonesian government.

In addition, the associated rise of private standards, driven primarily by Multi-NationalCorporate (MNC) company and by the supermarkets, have had a major impact on Indonesian food and beverage industry as retailers more to minimize their customers exposure to possible food illness, associated product recall and the potential for litigation. Moreover, it is realised that the assurance of today's consumers demands that this food supply is protected from : (1) contaminants by pathogenic microorganisms, chemical residues, and physical hazards; (2) decomposition; (3) adulteration, and (4) deception or fraud in the form of misleading claims and descriptions on labelling or in advertising (Haryadi and DewantiHariyadi, 2007).

\subsection{The Disincentives of QA Programs}

The main reasons for not implementing one or more QA programs (Part A) in their food business were regarding : (1) the high costs of QA implementation and maintenance of $Q A$ programs $(54.0 \%)$; (2) there was no need or no legal requirements $(31.0 \%)$; (3) the food food business was to small $(35.0 \%)$; (4) the lack of time (31.0\%); (5) the lack of information $(20.0 \%)$, and (6) the lack of resources $(39.0 \%)$.

Besides the uncertainty associated with the costs of implementing and maintaning the quality assurance (QA) programs, another major outcome of the personal interview was the factthat many resppondents $(30.0 \%)$ wondered why QA programs were necessary. For many, the need to implements QA systems was another impositions on their food business by regulators and retailers.

It was true, of course that quality and safety assurance affect the costs of carrying out transactions, and therein lies the incentive for adopting voluntary food quality assurance programmes (Holleran et al., 2000). Transaction costs are the costs of undertaking an exchange between buyers and sellers, including the monitoring and enforcement $s$ costs. Such costs are directly affected by, and may often increased by food safety regulations, product liability law and customer requirements (Hooleran et al., 2000).

Nevertheless, eventhough SMEs (small and medium enterprises) are said to contribute significantly to the economies of most countries, they are the least likely to comply with regulatory requirements because of resource constraints. Most studies have focused on large enterprises, independent of SMEs, arguing that is difficult to get responses from smaller enterprise, and hence there is a panciety of work in this area of a quality assurance programs (Mensah and Julien, 2011). So far, SMEs cannot afford the services of such professionals with the skills to develop, implement and maintain QA programs especially with food safety managements. Consequently, the financial related challenges arose from the costs involved in developing, implementing and continually maintaining a food safety management system.

Some of these costs arise from the regular refresher training for all staff members and occasional specialised training for specific quality staff. Other costs arise from the regular audits at planned intervals, to determine whether a food safety system as quality assurance programs conforms to planned arrangements and is effectively implemented and updated regularly (Mensah and Julien, 2011).

\subsection{Benefits/Advantages of QA Programs}

The increasing diversification of the business environment and the intensification of competition make the quality of products/service, the most important factors in ensuring economic competitiveness (Ionita et al., 2009). With the need to give much greater consideration to food safety, the environment and fair trade and equity, the concept of quality is rapidly expanding. Many quality assurance systems impose restrictions on production and practices or present technical barriers to trade (Henson and Reardon, 2005), especially for the developing countries (Jaffee and Masakure, 2005) including Indonesia. Therefore, If suppliers do not comply with customer requirements, they risk loosing market share and 
potential market exclusion. As a results, a number of food businesses are adopting quality assurance programs to improve their competitiveness or to satisfy customer requirements in the market (Marucheck et al., 2011).

While quality assurance (QA) may be an instrument to differentiate the product offer for many SMEs, the decision to implement a QA system is most often the results of customer pressures rather than benefits such as improved efficiency and effectiveness (Ojinnaka, 2011; Mensah and Julien, 2011). Ionita et al., (2009) argue that the benefits derived from QA can be grouped in two categories : internal benefits and external benefits. Firm driven (internal) factors include : (1) organizational benefits; (2) financial benefits; (3) people benefits; and (4) general benefits. Customer and regulatory driven (external) factors include : (1) commercial benefits; (2) communication benefits; (3) quality and safety benefits; and (4) general benefits.

The results of this study show that the main benefits or advantages for food businesses who are currently in the process of implementing one or more quality assurance programs (Part B) were include : (1) ensure and increase product safety and quality (20.0\%); (2) to gain new customers and/or additional customers (14.0\%); (3) continual improvement in the business culture, staff moral and awareness (17.0\%); (4) improve company image (10.0\%); and (5) establish a system of traceability to assure hygiene and food safety standards (8.0\%).

The main benefits or advantages arising from operating under one or more quality assurance (Part C) were perceived to be : (1) continual improvement in the food business structure or culture and improved staff moral $(31.0 \%)$; (2) reduced waste and reduced costs (17.0\%); (3) greater customer confidence and customer satisfaction leading to a better company image/reputation (16.0\%); (4) a traceability system in place which meets customers food safety standards $(10.0 \%)$; and (5) improved relationship with suppliers and customers $(7.0 \%)$.

\subsection{Barriers/Disadvantages of QA Programs} Generally, quality assurance practice is measured by : (i) new product design review procedures; (ii) design for manufacturing procedures; (iii) control of product and work specifications and procedures; (iv) preventive maintenance activities, and (v) quality control activities along the value added chain (Talib et al., 2013). Consequently, this construct is also concernedabout the quality assurance practices, consist of guidance, manual, standard, and etc., in the aspect of their implementation in the organization.

A review of the literature suggest that the challenges in implementing quality assurance programs in small business (including in small scale food production) are more difficult than in larger one; because of small size and limited resource (Talib et al., 2013) and structural features (Verbano and Venturini, 2013). The main difficulties small enterprises face in adopting and implementing a QA programs are : (1) small business do not often have profesonal quality managers, which results in the need to hire external consultants. At the same time, the food business does not have the internal business skills to evaluate and select those consultants; (2) SMEs have insufficient qualified staff to implement a quality assurance program; and (3) in most cases, the necessity for documentation is most well understood by the management (Rodringez-Escobar et al., 2006).

On the other hand, it can be argued that the barriers and constraints tothe adoption of quality assurance system by SMEs can be grouped into two main categories : internal barriers and external barriers (Soon and Baines, 2013). The internal barriers include : (1) inadequate resources; (2) unfavourable attitudes and perceptions; (3) implementation barriers; and (4) general barriers. The external barriers include : (1) insufficient support and guidance; (2) economic barriers; (3) the high costs of certifications and verifications, and staff/employee resistance.

The research has found that the main barriers which encountered or experienced by Indonesian food and beverage businesses in their decision to implement one or more quality assurance (QA) program (Part B) included : (1) the lack of time $(45.0 \%) ;(2)$ the highest cost of QA in implementation (38.0\%); (3) a negative attitudes of the increased amount of paperwork/duplication/documentation $(20.0 \%)$; (4) the high cost of QA certification (18.0\%); and (5) the lack of information (13.0\%).

For those food business operating under one or more quality assurance (QA) programs (Part $\mathrm{C}$ ) in Indonesia, the main barriers encountered in the introduction of QA programs included: (1) a negative attitude to the increased amount of paper work/duplication/documentation (28.0\%); (2) the high cost of QA certification and maintenance $(26.0 \%)$; (3) resistance of staff lower management $(20.0 \%)$; (4) lack of time $(15.0 \%)$, and $(5)$ the lack of staff training or education (18.0\%). 
As reported by Taylor (2013), for most small companies the adoption of quality assurance program require owner-managers to embark on a completely new system of managing food safety. They have little motivation for such change largely due to their firm belief that they produce safe food already. Whilst change in larger companies has been largerly customer driven, this has had little impact on smaller operations, many of whose customers are the end-user. It is also evident that the typical owner-manager has yet to be convinced that quality assurance program is either effective or practical in the context of their business.

The typical small business can be described as having a busy, day to day existence without designated staff to get involved in the long term planning of non-essential activities, i.e.. those not directly related to production. In larger companies the training and technical departments often lead the quality assurance (QA) program project; however, most small companies do not have these resources. It is evident, therefore that even if owner-managers can be convinced of the necessity for QA program, the allocation of sufficient "time" for its development becomes major constraining factor (Taylor, 2013; Fotopoulus et al., 2009). This is compunded by the requirement for specific training (HACCP, ISO 9000, GMP, etc.) and the need to access in the necessary technical expertise. To the small business, this translates into a heavy financial burden and most owners look to government or other agencies for external help at minimal cost (Ionita et al., 2009; Taylor, 2013).

One of the critisms made by small business trying to operate or implement the QA program system is its requirement for documentation. For many, especially microbusinesses, paper work of any kinds is a burden with verbal communication playing a major role in the successful management of their business (Talib et al., 2013; Taylor, 2013).

It is doubtful if any company can implement a quality assurance programs without specific training. This is particularly true for the small company with limited access to information and often without the time or skillss to interpret textbook scenarios. As a result, further specialist help is required which will consider the development, implementation and management of the system within the constraints of the small business.

Clearly, the major barriers to adoption of quality assurance (QA) programs included : (1) the increased paper work/beureaucracy; (2) the high cost of certification/verification; and (3) the lack of sufficient drivers or incentives to improve food quality. The main reason why SMEs do not use QA programs is because they perceive that it would increase their costs in time.

\section{CONCLUSIONS}

This paper has provided an overview of the issues associated with adoption of one or more quality assurance (QA) programs among SMEs in Indonesian food and beverage industry. In much of the literature on businees level decision making, the starting point is to look more closely at the actual decision making process and how these processes are influenced by external and internal constraints. In understanding the drivers, the benefits and barriers towards the adoption of $\mathrm{QA}$; it is important to recognise that the overall business aim must be to produce safe food.

Here it is important to recognise the value of $Q A$ in protecting the food and beverage industry in an environment of increasing distrust and as a means of differentiating the product in a congested market that may not only add value to their product but justify its higher price in the market.

\section{ACKNOWLEDGEMENT}

The authors would like to thank the Directorate of Tobacco and Beverage Industry, Directorate General of Agro Industry, Ministry of Industry Indonesia for providing funds for this project.

\section{REFERENCES}

Abdul, M., Ismail, H., Mustapha, M. \& Kusuma, H. (2013). "Indonesian small Medium Enterprises (SMEs) and perception on halal food certification". Afric. J. Buss Manag., 7, 16, 1492 - 1500.

Alkerman, R.; Farahari, P. and Grunov, M. 2010. "Quality, safety and sustainability in food distribution : A review of quantitative operations management approaches and challenges". Operation Res. Spectrum, 32, $863-904$.

Fatimah, ZSP. 2007. "Quality Management systems and product certification process and practices for SME in Indonesia". Paper presented at the National Workshop on Sub National Innovation systems and technology capacity building policies to enhance competitiveness of SMEs. Org. By UN-ESCAP and Indonesian Intitute of Science (LIPI).

Forsman, H. 2011. "Innovation capacity and innovation development in small Enterprises - A Comparison betwee the 
manufacturing and service sectors". Res. Policy, 40, 5, 739 - 750.

Fotopoulus, C.V., Kafezopolous, D.P. and Psomas, E.L. 2009. "Assessing the critical factors and their impact on the effective implementation of a food safety management system". Intl. J. Quality and Readability Manag., 26, 9, 891 - 910.

Hanida, AS; Noraelin, K.; Noraidah, SA and Hairulliza, MJ. (2009). "Statistical Process Control (SPC) in plastic packaging Manufacturing : A Case Study". Intl. Conference on Electronic Eng. \& Informatic.; August, 5-7;2009 - Selangor Malaysia : p. $199-203$.

Hariyadi, P. and Dewanti-Hariyadi, R. (2007). The need of communicating food safety in Indonesia. Dept. of Food technol. \& Human Nutr. Faculty of Agric. Technol., Agricultural Univ. Bogor - Indonesia.

Henson, S. (2008). "The role of public and private stnadards in regulating international food markets". J. Intl. Agric. Trade Dev. 4 : p. $63-81$

Hilman, MS and Ika Trinasari, F. (2014). "The factors that influence on the effectiveness implementation of HACCP system" (In Bahasa Indonesia). J. Standarisasi Vol. 16 No. 3 : p. $223-234$.

Holleran, E.; Bredahl, ME and Zaibet, L. (2000). "Private incentives for adopting food safety and quality assurance". Food Policy, 24 : p. $669-683$.

Indonesian Association of Food and Beverage or GAPMMI. (2012). "Economic of Indonesia in Second Quarterly Growth 6.5\%". Food Reveiew Indonesia Vol. VII No. 9, Sept : p. $26-27$.

Ionita, I.; Popescu, F.; Done, I.; Andrei, J.; Matei, M. and Subic, J. (2009). "Quality - A Factor for competitivenessimprovements for SMEs'. Economics \& Appl. Informatic.; Vol. XV No. 2 : p. $215-224$.

Irjayanti, M. and Azis, AM. (2012). "Barrier factors and potential solutions for Indonesia SMEs". Procedia Econ. and Finance 4 : p. $3-12$.

Jaffee, S. and Masakure, O. (2005). "Strategic use of private standards to enhance international copetitiveness : Vegetable exports from Kenya and elsewhere". Food Policy 30 (2005) : p. 316 - 333.

Johnston, EZ; Darroch, J. and Matear, S. (2011). "Business Orientation and Innovation in SMEs". Intl. Entrepreneurship. \& Manag. J. : p. $45-$ 54.
Judi, MM; jenaal, R. And Genasan, D. (2013). "Quality Control Implementation in manufacturing companies : Motivating factors and challenges". Applic. \& Experience of QCA : p. $495-520$.

Kurniawati, D. and Yuliando, H. (2015). "Productivity improvement of small medium Enterprises (SMEs) on food products : A Case at Yogyakarta province, Indonesia". Agric. \& Agric. Sci. Procedia 3 (2015) : p. $189-194$.

Marucheck, A.; Greis, N.; Mena, C and Cai, L. (2011). "Product safety and security in the global supplai chain : Issues, Challenges nd Research opportunities". J. Operation Management 29 : p. 707 - 720.

Mensah, LD and Julien, D. (2011). "Implementation of food safety management systems in UK". Food Control Vol. 22 Issue 8 : p. 1216 - 1225.

Mwamakamba, L.; Mensah, P.; Takyima, KA; Darkwah-Odame, J; Jallov, A. and Maiga, F. (2012). "Developing and maintaining National food safety control systems : Experiences from the WHO African region". Afric. J. Food Agric. Nutr. Development Vol. 12 No. 4 : p. 6291 6304.

Nababan, H.; Rahayu, WP; Sparinga, R.; Fardiaz, D.; Doughty, I. and Theobald, C. (2005). Reaching for stars - The Indonesian approach to food safety education. Poster paper presented in 4th Asian Conference on Food \& Nutrition Safety; March 2-5, 2005, Nusa Dua, bali Indonesia.

Najib, M.; Kiminami, A. and Yagi, H. (2011). "Competitiveness of Indonesian small and medium Food processing industry : Does the location matter ?". Int. J. Buss. \& Manag., Vol. 6 No. 9 : p. $57-66$.

National Body of Statistik or Badan Pusat Statistik/BPS. (2011). Indonesian statistic report of yearly (in Bahasa Indonesia). BPS, Jakarta.

OECD [Organization for Economic Cooperation and Development]. (2000). "Small and Medium Sized Enterprises : Local strength, global reach". OECD Policy Brief : p. 1 - $7 . \quad$ Hhtp ://www.oecd.org./department/13399.en.26 49.34197 : 11111.000. $\mathrm{html}$ (Acess at Oct., 12, 2014).

Ojinnaka, MC. (2011). "The food industry in Nigeria : Development and Quality Assurance". Pakistant. J. Nutr., 10 (6) : p . $589-593$. 
Othman, NM. (2010). "Food safety in Southeast Asia : Challenges Facing the Region". Asian J. Agric. \& Development Vol. 4 No. 2 : p. $83-92$.

Parilli, MD and Elola, A. (2011). "The strength of science and technology drivers for Small Medium Enterprises (SMEs) Innovation". Small Buss. Econ : p. $37-44$.

Pawitan, G. (2012). "Characteristic of Small and Medium Manufacturing Industries in the era of ACFTA : case study from west Jawa". Procedia Econ. and Finance 4: p. 130 - 139.

Rodrigez-Escobar, JA; Gonzalez-Benito, J. and Martinez-Lorente, AR. (2006). "An Analysis of the degree of small companies dissatisfaction with ISO 9000 certification". Total Qual. Manag. 17 (4) : p. 507 - 521.

Setyaningsih, S. (2012). "Using Cluster Analysis study to examine the succesful performance 6 in Indonesia". Procedia Econ. And Finance 4 : p. 286 - 298.

Sikora, T. (2005). "Methods and systems of food quality and safety assurance". Polish. J. Food \& Nutr. Sci., Vol. 14155 : p 41 - 48.

Soon, JM and Baines, RN. (2013). "Public and private food safety standards : facilitaating or frustracting fresh produce growers". Laws 2 : p. $1-19$.

Storer, CE. (2006). "Inter Organisional Information management systems and relationship in Agrobusiness Food chains of Organizations; PhD. Dissertation. Graduate School of Business, Curtain Univ. Of Technology. Perth, WA.

Tambunan, TH. (2009). "Export Oriented small and medium Industry clusters in Indonesia". J. Enterp. Comm. : People and Places in the Global Econ., Vol. 3 No. 1 : $25-58$.
Tambunan, TH. (2011). "Development of Small and Medium Enterprises in a developing country : The Indonesian case". J. Enterprising Comm : People and Places in Global Econ., Vol. 5 No. 1 : p. 68 - 72.

Taylor, E. (2013). HACCP in small companies : Benefits or burden? Lancashire Postgraduate School of Medicine \& Health, Univ. Of Central Lancashire, Preston, UK.

Thalib, HHA; Ali, KAM and Idris, F. (2013). "Quality management framework for the SMEs food processing industry in Malaysia". Intl. Food Res. J. 20 (1) : p 147 $-164$

Trienekens, J. and Zuurbier, P. (2008). "Quality and safety standards in the food industry, developments and challenges". Int. J. Produc. Econ., 113 : p. 107 - 122.

Unnevehr, L. and Ronchi, L. (2014). "Food safety and developing market - Research fundings and research gaps". Intl. Food Policy Res. Inst. (IFPRI) Discussion Paper, Sept. 2014. IFPRI, Washington DC - USA.

Verbano, C. And Venturini, K. (2013). "Managing risk in SMEs : A literature Review and Research Agenda". J. technol. Manag. \& Innovation Vol. 8 Issue 3 : p. $186-201$.

Whipple, JM; Voss, MD and Cloes, DJ. (2009). "Supply chain security practices in the food industry". Int. J. Physic. Distrib. \& Logistic Management 39 : p. 574 - 594. 